\title{
The Effects of Expectation Inflation on Aggregate Demand: Examining the South African Inflation Expectation Channel of South African Monetary Policy
}

\author{
T. Ncanywa* and O. Ralarala
}

\author{
School of Economics and Management, University of Limpopo, South Africa
}

\begin{abstract}
South Africa targeted inflation since February 2000 as its monetary policy framework to ensure long-run price stability and continues to pursue a target of $3-6 \%$ for headline CPI inflation. Monetary policy emphasises the importance of promoting economic growth that can be sustained and maintenance of low inflation in an economy. Therefore, the paper seeks to check whether a relationship between economic growth (GDP) and expectation inflation exists. The autoregressive distributive lag (ARDL) econometric methodology was employed to achieve the objectives. The ARDL bounds test found that there is a long-run cointegration between GDP and expectation inflation. Moreover, the ARDL results revealed that in the long run expected inflation had a negative significant effect on GDP. This implies that lower expectation inflation could stimulate economic growth. It is recommended that South Africa should continue to target inflation because its target band of $3 \%$ to $6 \%$ keep policy makers on the loop.
\end{abstract}

Keywords: Monetary policy transmission mechanism, price stability, economic growth, expectation inflation, Autoregressive Distributive Lag.

\section{INTRODUCTION}

Inflation targeting has been used in South Africa since February 2000 in its monetary policy. Under this framework, a clear inflation target is set by the SARB which is then announced to the public for the mediumterm. The SARB continues to pursue a target of $3-6 \%$ for headline $\mathrm{CPI}$ inflation. A famous feature of an inflation-targeting framework is bringing transparency to monetary policy (Bernanke, 2003). Monetary policy is at the centre of discussions on how to promote economic growth and at the same time maintain low inflation in an economy. To achieve the main goal of monetary policy which is price stability, the SARB remains committed to inflation targeting (SARB, 2004). The Bank announces a clear inflation target and designs policies in order to achieve this target (Mishkin, 2000).

Thus, an investigation on monetary transmission mechanism is of great importance to ensure appropriate policy actions in South Africa (de Waal \& van Eyden, 2012). Smal \& de Jagar (2001) support this by emphasizing that, since long lags are usually found in the transmission mechanism, it is of great importance to study and analyze the chain of events brought about fluctuations in SARB's repurchase rate. Predicting only in which direction variables change due to a directional change in monetary policy is not

\footnotetext{
*Address correspondence to this author at the School of Economics and Management, University of Limpopo, South Africa; Tel: 0152684322; Fax: 0152683522; E-mail: thobeka.ncanywa@ul.ac.za

JEL Codes: E31, E52, O23.
}

enough, but it is significant that policy makers take into account the most appropriate monetary policy transmission channel to influence the economy (Bain \& Howells, 2003).

The short-term interest rate charged by the Reserve Bank in money markets is determined by the Monetary Policy Committee (MPC). Decisions about the official interest rates affect economic activity and inflation through several channels, which are known collectively as the transmission mechanism of monetary policy (Van den Heever, 2001). Most studies that discuss the monetary policy transmission mechanism focus mainly on the interest rate channel (Bernake and Gertler, 1995; Mishkin, 1995; Mojon, 2000; Bruno and Shin, 2015), which was regarded as the main channel. Also, a number of authors that discuss the channels of monetary policy transmission leave the expectations channel out completely (Bernanke 1990; Mishkin, 1995; Favero, Giavazi and Flabbi, 1999). The above are some of the reasons that steered interest on examining the expectation inflation channel of monetary policy transmission of South Africa. Based on the contradictions found in literature, this study contributes by indicating which direction the monetary policy should take regarding this channel. An investigation of monetary policy transmission mechanism is still of greater importance as one of the ways to help monetary authorities take appropriate decisions concerning output and expectation inflation in South Africa (De Waal and Van Eyden, 2012). Being aware of only the direction of change taken by variables due to changes in monetary policy is not 


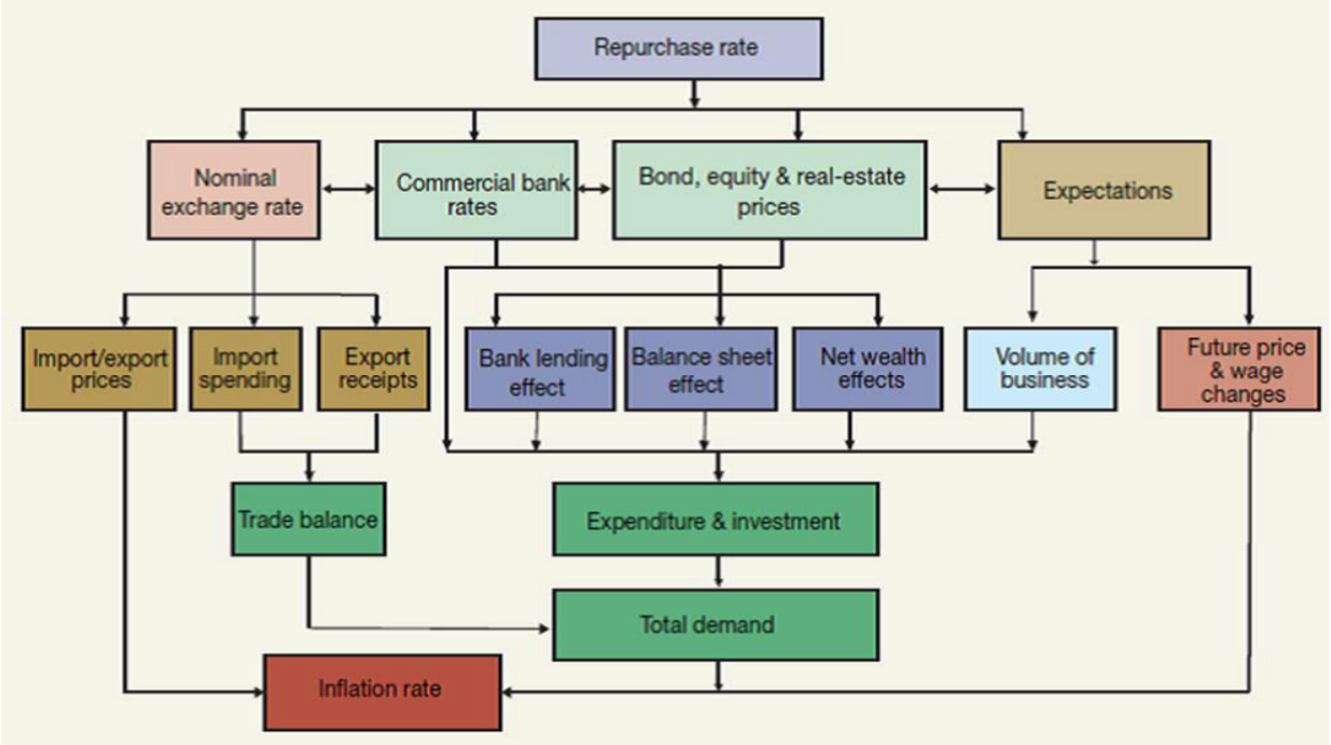

Figure 1: The channels of monetary policy transmission in South Africa.

Source: The SARB, 2004.

enough. It is also important to know how much time, for example, it takes for the rate of expectation inflation and output to change due to a change in the repurchase (repo) rate (Bain and Howells, 2003). Smal and de Jager (2001) support this argument by emphasizing that, because of these lags in the transmission mechanism, changes in expectation inflation and output due to changes in the repo rate need to be studied closely.

Figure 1 displays the channels of monetary policy transmission mechanism in South Africa. In Figure 1, it can be seen that all the channels begin when the Reserve bank make use of repurchase rate (repo rate). The repo rate is the rate charged by the Reserve Bank when lending private banks money (Smal and de Jagar, 2001). Decisions taken by the SARB in the future change in the repo rate determine how economic agents view reaction by the Reserve Bank on different economic shocks (De Waal and van Eyden, 2012). The expectation channel proceeds to expenditure and investment, whereby the agents' expectations determine how they choose to divide their resources between spending and investing decision, which can ultimately affect total demand and prices. Then the total demand influences the inflation rate.

Łyziak (2010) claims that the agents' expectations highly depend on how credible the Reserve Bank seems to be on their own analysis. If the agents perceive the SARB to be serious about inflation, their expectations on the future price will fasten around the central bank inflation targets. Duffee (2015) also argued that if the agents expect the Reserve Bank to accommodate more output in comparison to price stability; their expectations about future price will react the opposite. This paper aims to review how expectation inflation affects aggregate demand in a monetary policy transmission mechanism. Therefore, the focus is on the relationship between expectation inflation and aggregate demand in South Africa. This paper is structured as follows; the next section examines the theoretical and empirical literature, third section examines the research methodology, fourth section gives empirical results and discussion. The last section concludes and gives policy recommendations.

\section{LITERATURE REVIEW}

\subsection{Theoretical Literature}

The first view, Keynesian theory, was developed by John Maynard Keynes during the 1930s. Keynesians claimed that monetary policy transmission has an indirect effect on variables such as money supply and aggregate demand (Smal \& de Jager; 2001). This effect takes place through changes in the interest rate. Changes in interest rate could trigger changes in output and money supply. Secondly, the classical theory viewed variables such as output and employment as immune to changes in money supply (Fisher, 1930). Under this theory, the inverse relationship between money supply and prices hold. The third view is the monetarist theory view whereby if money supply 
increases, people will hold more money than they prefer to hold. The surplus money is therefore spent in the purchase of securities, goods and services thus causing an increase in aggregate demand. The monetarists argued that the transmission mechanism is significant for controlling money supply and aggregate demand in the long-run. This happens through portfolios used by different players in the economy such as households and firms to hold their wealth (Taylor, 1995). The fourth is the neo-Keynesian theory stipulated that changes in money supply lead to different effects such as the wealth and substitution (Mojon, 2000).

\subsection{Empirical Literature}

The World Bank (2013) expected Ghana's GDP to rise at least by $8 \%$ in order to accomplish the Millennium Development Goals but the real growth averaged around 5\% since 1990. Ahiakpor and Akapare (2014) discovered that the reason behind Ghana's economic growth being inconsistent is because Ghanaian monetary policy makers have been failing to achieve its inflation target over the period 1986 to 2012. This means that the actual inflation over that period in Ghana has been higher than the expectation inflation. This led to the actual levels of GDP tend to be lower than the expected GDP levels.

In analyzing the household inflation expectations and inflation dynamics, Gabriel (2010) emphasized the importance of managing inflation expectations as it plays the main role in determining current inflation in the long run, amongst other determinants. In modern monetary economics, it is largely assumed that the rate of expectation inflation plays a huge role when economic agents and household determine the rate of aggregate demand, but there is limited empirical evidence to support this assumption. To discover the connection between aggregate demand and inflation on the country's demand side, it should be known how the real rate of interest connects to these two variables (Sorensen and Whitta-Jacobsen, 2003). The authors' hypothesis of total demand curve assumes that monetary policy follows the Taylor rule, which infers that the central bank raises the real rate of interest when the inflation rate increases. This means a rise in the expectation inflation rate will result to a fall in aggregate demand.

Kirmanoglu (2001) used the VAR models to show that expected high inflation rates in Turkey lead to a decrease economic growth. Using the VAR and the
GARCH model, Mendoza (2003) also supported this evidence of a trade-off between inflation and output for Turkey. Agenor and Hoffmaister (1997) conducted a study on emerging economies on aggregate demand and expected inflation, and employed a VAR analysis to study the short run relationship among inflation, productivity, nominal wages and exchange rate. Their findings showed that when the exchange rate depreciates, the rate of both inflation and expected inflation goes down but output increases. An investigation of the South African inflation-output tradeoff in South Africa, Ngalawa and Komba (2015) found a negative demand shock to reduce inflation and expectation inflation whereas a similar positive demand shock results to a minor rise in inflation and a larger increase in output.

According to Pretorius (2013) agents' inflation expectations are dependent on past records of inflation rates and policy makers' behavior. Therefore, if inflation increases from the previous periods, growth will be adversely affected (Singh and Kalirajan, 2003). Most researchers argue that inflation negatively affect growth only after it crosses a threshold limit below which, inflation has a positive effect. This is not always true. For example, Singh and Karilajan (2003) investigated the inflation-growth nexus for India. The authors discovered that India does not have a threshold level but it is best for the country to maintain low levels of inflation, as much as literature argues that low inflation may hurt growth.

Making use of the Johansen's approach, MitchellInnes (2006), investigated a South African case of an expected inflation- Interest rate nexus. A weak long run relationship was discovered between the two variables in question. Mitchell-Innes (2006) explains that this was an indication that the long-term real Interest had not been constant since the adoption of inflation-targeting and that monetary policy has had an influence on the long-term real Interest rate. This supports an argument by Alimi \& Ofunyelu (2013) that variations in expected inflation move in the same direction as the nominal Interest rate; but the movement is not on one-on-one basis.

Wesso (2000) studied the long-term yield bonds and expected inflation nexus in South Africa for the period 1985-1992 using the error correction model. The discoveries showed that the bond yield is cointegrated with the inflation rate over the period, 1985-1999, an indication that in the long-run, perpetual movements in expected inflation associate with perpetual movements 
in the long-term bond yield. Using the Johansen (1988), Johansen, and Juselius (1990) procedure, Payne and Ewing (1997) assessed the monetary transmission mechanism for nine emerging economies. The study showed an existence of a long-run nexus between nominal Interest rates and inflation for Pakistan, Singapore, Sri Lanka and Malaysia. In contrast, Wijesinghe, (2002) discovered no nominal Interest rate-inflation nexus for Sri Lanka.

\section{METHODOLOGY}

This section explains the research methodology adopted by specifying the model, data issues and estimation techniques of the model. The study used secondary time series data on a quarterly basis for the period 2000-2017, and data was obtained from the South African Reserve Bank (SARB). The model has been developed in accordance to the expectation channel of South African monetary policy transmission mechanism and some literature reviewed (Gabriel, 2010; Kirmanoglu, 2001; SARB, 2000). The linear model is as follows,

$L G D P_{t}=\alpha+\beta_{1} \pi_{t}^{e}+\beta_{2} R R_{t}+\beta_{3} L P C_{t}++\beta_{4} L I_{t}+\varepsilon$

Where: $L G D P_{t}$ is logged gross domestic product proxy for aggregate demand, $\pi_{t}^{e}$ is expectation inflation, $R R_{t}$ is repo rate, $P C_{t}$ is private credit representing the financial development activity of businesses; and $I_{t}$ represent investment spending. $\alpha$ represent the constant, $\beta$ the coefficients of the explanatory variables, $L$ logarithm to standardize the variables in values; and $\varepsilon$ is the error term.

The first step taken was to check stationarity of specified variables using the Augmented Dicky Fuller test and the Phillips Perron (Dickey, 1976; Dickey \& Fuller, 1979; Phillips, 1986; Phillips \& Perron, 1988). The staionarity test is important to avoid the existence of spurious regression, and to find out the order of integration to decide which econometric methodology to be used (Brooks, 2008; Gujarat and Porter, 2009; Mutyaba, 2013).

To estimate the relationship between aggregate demand and expectation inflation both in the long and short run, the study employed the autoregressive distribution lag (ARDL) as established by Perasan, Shin, \& Smith (2001). The ARDL model can be chosen if the variables under investigation are integrated at different orders such as $\mathrm{I}(0)$ and $\mathrm{I}(1)$ (Pesaran et al., 2001). The ARDL is advantageous as it eliminates inconclusive inferences through the bounds test. Furthermore, the ARDL allows small sample data to be used in the model without giving spurious results, and can accommodate structural break in the time series data.

To determine the existence of a long-run relationship in the series Pesaran et al. (2001) presented the ARDL bounds test that uses the F-test of the joint significance of the coefficients of lagged level variables. The ARDL bounds test approach to cointegration testing assumes that each variable is treated as the dependent variable, sequentially, and regressed on the other variables (Brooks, 2008). The study proceeds to employ the CUSUM stability tests.

The variance decomposition test was estimated to indicate the quantity of information expectation inflation contributes to the levels of aggregate demand in the auto-regression (Powers \& Yun, 2009). Then, the impulse response functions were employed to determine the reaction of aggregate demand shocks to changes in expected inflation.

\section{RESULTS AND DISCUSSION}

This section presents the findings of the study as estimated using the e-views software. Table 1 shows the unit root test results conducted using both the Augmented Dicky Fuller (ADF) and Phillips-Perron (PP) tests for all five variables.

Aggregate demand (LGDP), investment (LI), private credit (LPR) and the repo rate (RR) were all found to be nonstationary on levels and stationary on $1^{\text {st }}$ difference (Table 1). Expectation inflation $\left(\pi^{e}\right)$ was found to be stationary at levels for both the ADF and the PP and we therefore reject the null hypothesis at 0.05 level. The unit root test results for both the PP and ADF showed that the specified variables are integrated of different orders, therefore the study employed the ARDL bounds test developed by Pesaran et al. (2001).

Table 2 presents the ARDL Bounds test results for cointegration. The calculated F-statistics of 10.19 is greater than both the lower bounds (3.25) and the upper bounds (4.49) at $1 \%$ levels (and all other levels) implying that there is cointegration in the model. In econometrics the existence of cointegration imply a long term relationship between the variables (Brooks, 2008). Consequently, a significant long run relationship in the aggregate demand-expectation inflation series can be presumed. 
Table 1: Augmented Dickey Fuller and Phillip-Perron Test Results

\begin{tabular}{|c|c|c|c|c|c|}
\hline Order of Integration & Variable & \multicolumn{2}{|c|}{ AUGMENTED DICKEY FULLER } & \multicolumn{2}{|c|}{ PHILLIPS- PERRON } \\
\hline Level & LGDP & $\begin{array}{c}-1.992203 \\
(-2.903566)\end{array}$ & $\begin{array}{c}-0.942175 \\
(-3.475305)\end{array}$ & $\begin{array}{c}-2.388437 \\
(-2.902953)\end{array}$ & $\begin{array}{c}-0.612431 \\
(-3.474363)\end{array}$ \\
\hline $1^{\text {st }}$ Difference & & $\begin{array}{l}-4.468880^{*} \\
(-2.903566)\end{array}$ & $\begin{array}{l}-4.891939^{*} \\
(-3.475305)\end{array}$ & $\begin{array}{l}-4.468880^{*} \\
(-2.903566)\end{array}$ & $\begin{array}{l}-4.846598^{\star} \\
(-3.475305)\end{array}$ \\
\hline Level & $\mathrm{LI}$ & $\begin{array}{c}-2.296358 \\
(-2.903566)\end{array}$ & $\begin{array}{l}-0.778890 \\
(-3.475305)\end{array}$ & $\begin{array}{c}-2.157471 \\
(-2.902953)\end{array}$ & $\begin{array}{c}-0.547688 \\
(-3.474363)\end{array}$ \\
\hline $1^{\text {st }}$ Diff & & $\begin{array}{l}-4.625168^{*} \\
(-2.903566)\end{array}$ & $\begin{array}{l}-5.211814^{*} \\
(-3.475305)\end{array}$ & $\begin{array}{l}-4.553954^{*} \\
(-2.903566)\end{array}$ & $\begin{array}{l}-5.225528^{*} \\
(-3.475305)\end{array}$ \\
\hline Level & RR & $\begin{array}{l}-2.504887 \\
(-2.903566)\end{array}$ & $\begin{array}{l}-3.410542 \\
(-3.475305)\end{array}$ & $\begin{array}{c}-1.840293 \\
(-2.902953)\end{array}$ & $\begin{array}{c}-2.209907 \\
(-3.474363)\end{array}$ \\
\hline $1^{\text {st }}$ Diff & & $\begin{array}{l}-4.953353^{*} \\
(-2.904198)\end{array}$ & $\begin{array}{l}-4.958898^{*} \\
(-3.476275)\end{array}$ & $\begin{array}{l}-4.066128^{*} \\
(-2.903566)\end{array}$ & $\begin{array}{l}-4.052480^{*} \\
(-3.475305)\end{array}$ \\
\hline
\end{tabular}

Source: Author's computation using E-views 9.

Notes: * denotes the rejection of the Null hypothesis at 0.05 levels.

Critical values are in parenthesis ().

Table 2: Summary of ARDL Bounds Test Results

\begin{tabular}{|c|c|c|}
\hline \multicolumn{3}{|l|}{ Calculated F-Statistic: 10.18807} \\
\hline \multicolumn{3}{|c|}{ No. of independent variables: $k=4$} \\
\hline \multicolumn{3}{|l|}{ Case: Trend } \\
\hline Significance: & Lower bounds & Upper bounds \\
\hline $1 \%$ & 2.45 & 3.52 \\
\hline $5 \%$ & 2.86 & 4.01 \\
\hline $10 \%$ & 3.25 & 4.49 \\
\hline
\end{tabular}

Source: Author's computation using E-views 9.

Table 3: Long-Run Test Results

\begin{tabular}{|c|c|c|}
\hline VARIABLE & COEFFICIENT & PROBABILITY \\
\hline \hline$\pi^{e}$ & -0.004539 & $0.0619^{*}$ \\
\hline LPR & -3.618865 & $0.0719^{*}$ \\
\hline LI & 5.5973578 & $0.0115^{* * *}$ \\
\hline RR & -0.001666 & 0.1734 \\
\hline C & -15.582742 & $0.0501^{* *}$ \\
\hline
\end{tabular}

Source: Author using E-views computation.

Notes: ${ }^{* \star * ; * * *}$ indicates the rejection of the null hypothesis at $1 \%, 5 \%$ and $10 \%$ level respectively.

The ARDL approach was employed in prediction of both the long and short-run relationship in the series.
Table 3 provides estimated long run results of the ADRL model. 
Table 4: The ARDL Short-Run Results

\begin{tabular}{|c|c|c|}
\hline Variable & Coefficient & Probability \\
\hline \hline D(EXP_INFL) & -0.000282 & 0.2858 \\
\hline D(LPRIV_CRED) & -0.557527 & $0.0002^{* * *}$ \\
\hline D(LINV) & 8.623368 & $0.0001^{* * *}$ \\
\hline D(REP_RATE) & 0.002020 & $0.0000^{* * *}$ \\
\hline ECM(-1) & -0.154061 & $0.0074^{* * *}$ \\
\hline
\end{tabular}

Source: Author's compilation using E-views.

Notes: ${ }^{* * *}$ indicates the rejection of the null hypothesis in $10 \%$ level.

Expectation inflation $\left(\pi^{e}\right)$, private credit (LPR) and the repo rate $(R R)$ have a negative relationship on GDP. On the other hand, investment (LI) is positively related to GDP. However, only investment is significant at $1 \%$ level while expectation inflation and private credit were significant at $10 \%$ level with the repo rate seen as insignificant. This implies that in the long-run, a $1 \%$ increase in the rate of expectation inflation would lead to $0.4 \%$ decrease in the levels of aggregate demand. These results indicated that future expectations of low inflation can strengthen aggregate demand and this is favourable to the economy. These findings are in agreement with the theoretical aspects reviewed in literature that the expectation inflation channel can be sustained and be considered in South Africa (SARB, 2004). However, there are some contradictions in literature as seen from Singh and Kalirajan (2003) in the Indian inflation-growth nexus. Table 4 shows the short-run results found using the ARDL approach.

In the short run, the ARDL test showed that as much as the relationship between aggregate demand and expectation inflation rate is still negative, but it is insignificant (Table 4). This means that the rate of expected inflation does not really explain the behavior of levels of aggregate demand in the short run. Table 4 further shows that the error correction model (ECM) as
$-15.5 \%$ significant at $1 \%$ implying that the model will subsequently correct itself over time, adjust and reach equilibrium. Then, next stage was to test whether there is stability in the model specification, and this was done by running the CUSUM test and the CUSUM of square test as revealed in Figures 2 and 3 respectively.

According to the CUSUM test in Figure 2, the cumulative line moves inside the two critical lines, which reveals that the model specification is stable, and the estimates can be relied upon. Additionally, we run the CUSUM square to verify with certainty that indeed the model is stable, and the CUSUM of square, Figure 3, endorse the CUSUM test.

Figure 4 provides the results of the impulse response functions revealing how aggregate demand responds to shocks from each variable in this time series. It is indicated that aggregate demand responds positively to its own shocks across all the periods from quarter one to the tenth quarter. With regards to expectation inflation and aggregate demand reaction, there is a negative shock across all periods. This is revealed by the blue line fluctuating below the mean of zero on the graph throughout from the first to the tenth quarter (Figure 4).

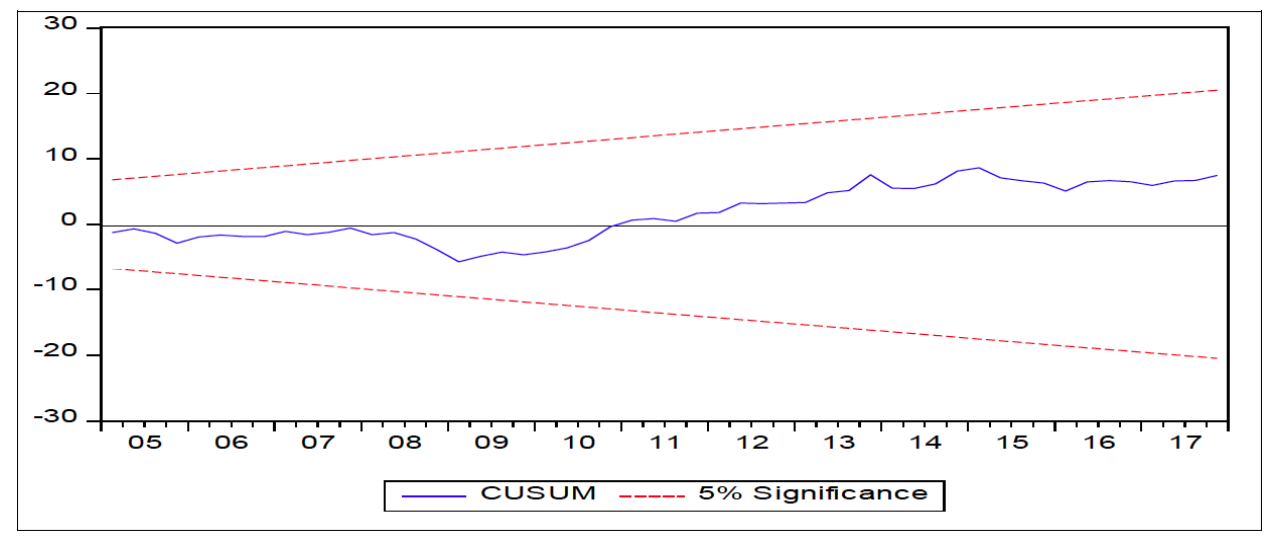

Figure 2: Cusum test. 


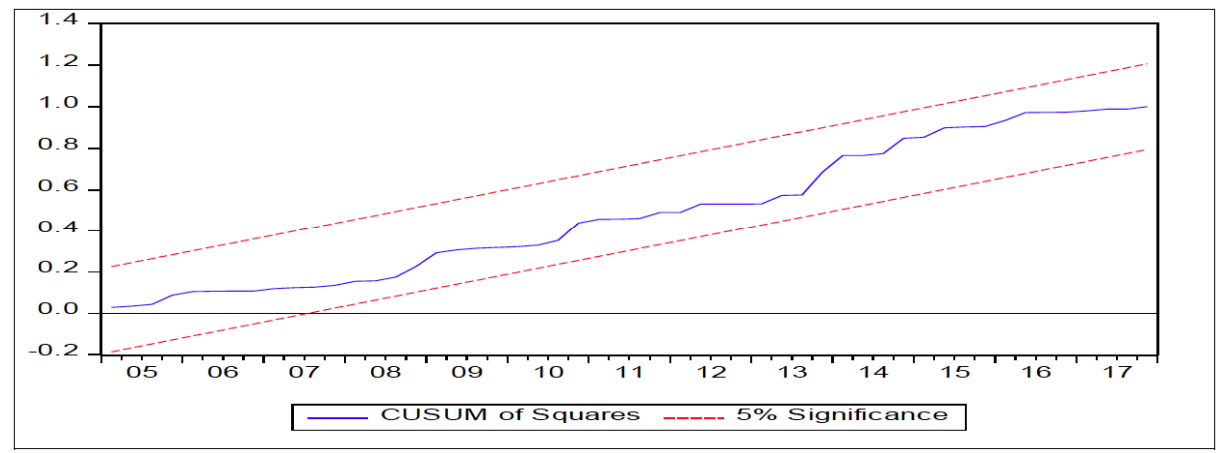

Figure 3: CUSUM of squares.

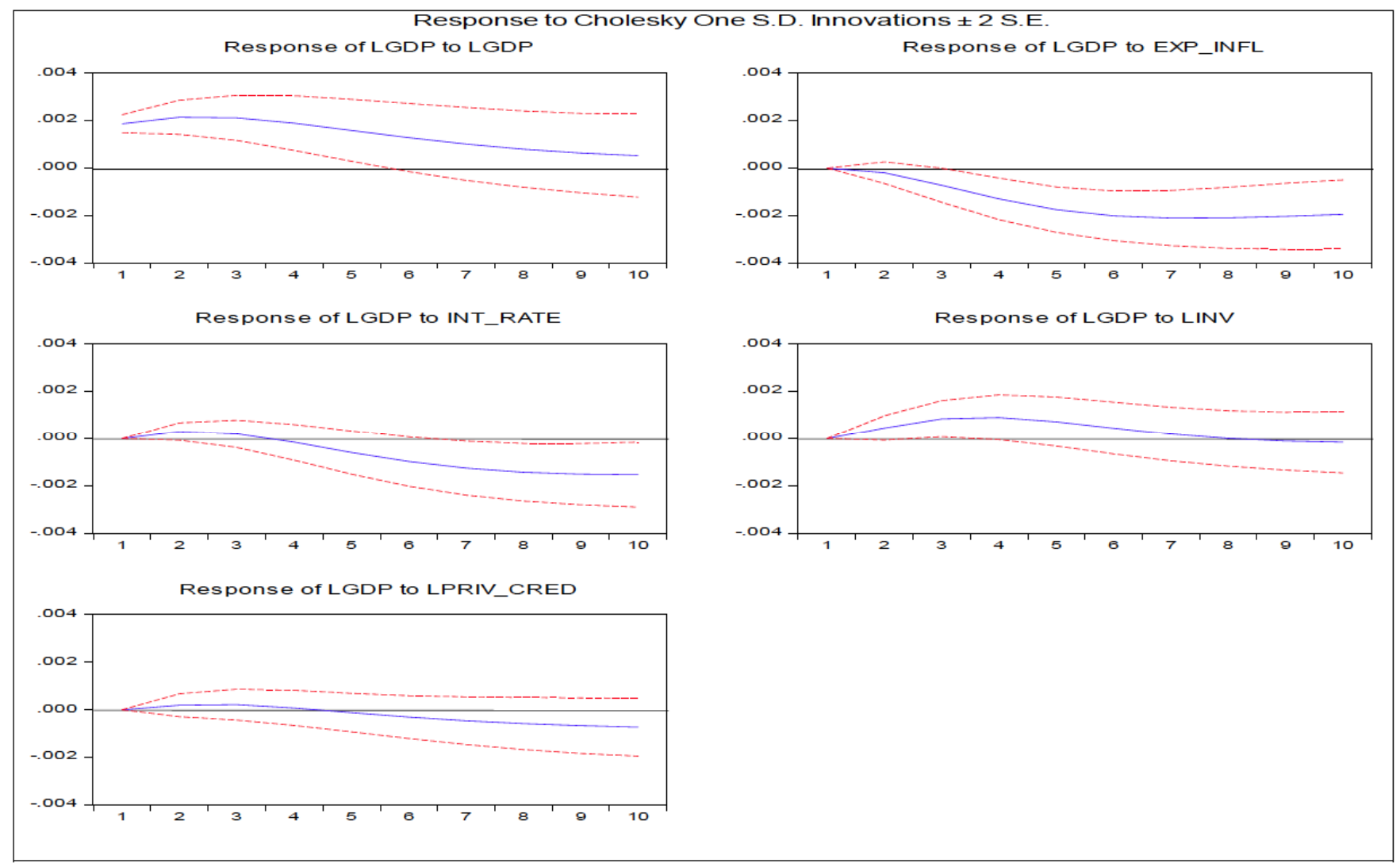

Figure 4: Impulse response test results.

Source: Author's compilation from EViews software.

Table 5 summarizes the results of variance decomposition to forecast the reaction of the regressed variable against the independent variables. The shortrun effect is represented by the third quarter and the long-run is represented by the tenth quarter. The cause and effect on the regressed variables cause $88.08 \%$ fluctuation in the short-run. While expectation inflation causes a $3.98 \%$ fluctuations in GDP; and investment causes a $6.45 \%$ fluctuation in GDP in the short-run. However, the repo rate and private credit have an even more less impact on the GDP, with $0.90 \%$ and $0.56 \%$ respectively.
In the long-run, fluctuations in the GDP through its own cause and effect diminish quite significantly by $52.11 \%$ to $35.97 \%$ (Table 5). Expectation inflation in the long-run has a significant impact on aggregate demand forecast variation. That is, a $41.75 \%$ of fluctuations in aggregate demand are caused by expectant inflation in the long-run. These empirical findings hold theoretically as expectation inflation has been proven to alter consumer spending and act accordingly. This is so because as consumers expect the rate of inflation to increase, the level of spending will increase because the value of money will 
Table 5: Summary of Variance Decomposition Test Results

\begin{tabular}{|c|c|c|c|c|c|c|}
\hline \multicolumn{7}{|c|}{ Variance Decomposition of LGDP: } \\
\hline Period & S.E. & LGDP & $\pi^{e}$ & RR & LI & LPR \\
\hline \hline 1 & 0.001865 & 100.00 & 0.000 & 0.000 & 0.000 & 0.000 \\
\hline 3 & 0.003766 & 88.084 & 3.987 & 0.906 & 6.456 & 0.564 \\
\hline 10 & 0.007914 & 35.975 & 41.752 & 15.486 & 4.011 & 2.774 \\
\hline
\end{tabular}

Source: Author's computation using E-views 9.

depreciate and thus will spend less in the future. Similarly, the repo rate causes GDP to fluctuate significantly in the long-run at $15.48 \%$, as a result the reserve bank uses the repo rate as an instrument to control the inflation rate. Investment and private credit are still having a minimal shock impact on GDP at $4.01 \%$ and $2.77 \%$ respectively.

\section{CONCLUSION AND RECOMMENDATIONS}

The study aimed to evaluate the inflation expectations channel of the South African monetary transmission mechanism in the period 2000-2017, on a quarterly basis. The study employed the autoregressive distributive lag (ARDL) method to unlock the relationship between the aggregate demand (GDP) and expected inflation $\left(\pi^{e}\right)$, while other variables were included to control any white noise in the model.

The ARDL bounds test showed that there was cointegration in the model specified, which means there is a long-run relationship in the series. However, the relationship did not hold in the short run. As such, the ARDL confirmed a negative long run significant relationship between aggregate demand and expectation inflation. This means that when economic agents expect inflation to rise it could have adverse effects on aggregate demand. Additionally, the ARDL error correction model confirmed the adjustment of the model to self-correct towards equilibrium at the speed of about $15 \%$.

It is recommended that South Africa should continue using inflation targeting as its monetary policy framework because its target band of $3 \%$ to $6 \%$ assist the policy makers to know when deviating from the target. As such, the study maintains a popular recommendation that "if not kept in check, inflation can erode saving, discourage investment, course capital flight and cause social and political unrest" (Menon, 2017). Among the other channels of monetary policy transmission expectation inflation channel deserves to be put on a high pedestal. As Barro (2013) puts it bluntly that, most businesses and households perform poorly when inflation is unpredictable.

\section{REFERENCES}

Agenor, P.R., \& Hoffmaister, W. A., (1997). Money wages and inflation in middle-income developing countries. IMF Working Paper. https://doi.org/10.5089/9781451976991.001

Ahiakpor, F., \& Akapare, I. A. (2014). Short-run and long-run inflation and economic growth nexus in Ghana. Ghana Journal of Development Studies, 11(2), 32-49. https://doi.org/10.4314/gids.v11i2.3

Bain, K. \& Howells, P. (2003), Monetary Economics: Policy and its theoretical application. Hampshire: Palgrvave Macmillan.

Barro, R. J. (2013). Inflation and economic growth. Annals of Economics \& Finance, 14(1).

Bernanke, B. (1990). The federal funds rate and the channels of monetary transnission (No. w3487). National Bureau of Economic Research https://doi.org/10.3386/w3487

Bernanke, B. (2003). A perspective on inflation targeting: why it seems to work. Business Economics, 38(3), 7-16.

Brooks, C. (2008). RATS Handbook to accompany introductory econometrics for finance. Cambridge Books. https://doi.org/10.1017/CBO9780511814082

Bruno, V., \& Shin, H. S. (2015). Capital flows and the risk-taking channel of monetary policy. Journal of Monetary Economics, 71, 119-132.

https://doi.org/10.1016/j.jmoneco.2014.11.011

De Waal, A., \& Van Eyden, R. (2012). The Monetary Transission Mechanism in South Africa: A VECM augmented with foreign variables. 1-31. https://doi.org/10.1111/saje.12027

Dickey, D. A. (1976). Estimation and hypothesis testing in nonstationary time series.

Dickey, D., \& Fuller, W. (1979). Distribution of the estimator for autoregressive time series. Journal of Statistical Association, 428-430.

Gábriel, P. (2010). Household inflation expectations and inflation dynamics (No. 2010/12). MNB Working Papers.

Favero, C. A., Giavazzi, F., \& Flabbi, L. (1999). The transmission mechanism of monetary policy in Europe: evidence from banks' balance sheets (No. w7231). National bureau of economic research.

https://doi.org/10.3386/w7231

Johansen, S. (1988), 'Statistical Analysis of Cointegration Vectors', Journal of Economic Dynamics and Control 12, 231-254. https://doi.org/10.1016/0165-1889(88)90041-3

Johansen, S. \& Juselius, K., (1990). Maximum likelihood estimation and inference on cointegration - with applications to the demand for money. Oxford Bulletin of Economics and Statistics. 52(2).169-210. https://doi.org/10.1111/j.1468-0084.1990.mp52002003.x 
Kirmanoglu, H., (2001). Is there inflation-growth tradeoff in the Turkish economy? Canadian Economic Association Conference.

Łyziak, T., (2010). Measurement of perceived and expected inflation on the basis of consumer survey data. Bank for Internat. Settlements.

Menon, S. (2017). Ten things you need to know about inflation targeting. https://doi.org/10.1002/rwm3.20661

Mishkin, F. S. (1995). Symposium on the monetary transmission mechanism. Journal of Economic perspectives, 9(4), 3-10. https://doi.org/10.1257/jep.9.4.3

Mishkin, F. S. (2000). Inflation targeting in emerging-market countries. American Economic Review, 90(2), 105-109. https://doi.org/10.1257/aer.90.2.105

Mishkin, F. S. (2001). The transmission mechanism and the role of asset prices in monetary policy (No. w8617). National bureau of economic research. https://doi.org/10.3386/w8617

Mitchell-Innes, H. A. (2006), The Relationship between Interest Rates and Inflation in South Africa: Revisiting the Fisher's Hypothesis. A Masters Thesis Submitted to Rhodes University, South Africa

Mojon, B. (2000). Financial structure and the interest rate channel of ECB monetary policy.

Ngalawa, H. \& Komba, C. (2015), Inflation-Output Trade-Off in South Africa: Is the Phillips Curve Symmetric? African Economic Research Consortium, 1(1),1-29

Payne, J. E. and Ewing, B. T. (1997), Evidence from Lesser Developed Countries on the Fisher Hypothesis: A Cointegration Analysis, Applied Economics Letters 4, 683687. https://doi.org/10.1080/758530649

Persaran, H., \& Shin, Y. (1998). Gerelalised impulse response analysis in linear multivariate models. ScienceDirect, 18-28.

Pesaran, M. H., Shin, Y., \& Smith, R. J. (2001). Bounds testing approaches to the analysis of level relationship. Journal of Applied Econometrics, 16(3), 289-326. https://doi.org/10.1002/jae.616
Phillips P. C B. \& Perron, P., 1988. Testing for unit root in

Phillips, P. C. (1986). Understanding spurious regressions in econometrics. Journal of econometrics, 33(3), 311-340. https://doi.org/10.1016/0304-4076(86)90001-1

Phillips, P., \& Perron, P. (1988). Testing for a unit root in time series regressions. Biometrika, 336-346. https://doi.org/10.1093/biomet/75.2.335

Powers, D., \& Yun, M. (2009). Multivariate Decomposition for Hazard Rate Models. American Sociological Association, 233-263. https://doi.org/10.1111/j.1467-9531.2009.01211.x

Savvides, A. (1998). Inflation and monetary policy in selected West and Central African countries. World Development, 26(5), 809-827. https://doi.org/10.1016/S0305-750X(98)00018-7

Singh, K., \& Kalirajan, K. (2003). The inflation-growth nexus in India: an empirical analysis. Journal of Policy Modeling, 25(4), 377396. https://doi.org/10.1016/S0161-8938(03)00011-5

Smal, M., \& De Jager, S. (2001). The Monetary Tansmission Mechanism in South Africa. Pretoria: South African Reserve Bank. Occasional Paper 16

Sorensen, P. B., Whitta-Jacobsen,H.J. (2003). Output and Inflation in the Short Run: Aggregate Supply and Aggregate Demand

Taylor, J., (1995), The Monetary Transmission Mechanism: An empirical framework, Journal of Economic Perspectives, 9(4), 11-26. https://doi.org/10.1257/jep.9.4.11

Taylor, J. B. (2001). The role of the exchange rate in monetary-policy rules. American Economic Review, 91(2), 263-267. https://doi.org/10.1257/aer.91.2.263

Van den Heever, J. P. (2001). A note on inflation targeting in South Africa. South African Journal of Economics, 69(1), 168-177. https://doi.org/10.1111/j.1813-6982.2001.tb00007.x

Wesso, G. R. (2000). Long-term bond yields and future inflation in South Africa: a vector error-correction analysis. South African Reserve Bank: Quarterly Bulletins , 73-84.

\section{DOI: https://doi.org/10.6000/1929-7092.2020.09.41}

(C) 2020 Ncanywa and Ralarala; Licensee Lifescience Global.

This is an open access article licensed under the terms of the Creative Commons Attribution Non-Commercial License (http://creativecommons.org/licenses/by-nc/3.0/) which permits unrestricted, non-commercial use, distribution and reproduction in any medium, provided the work is properly cited. 